\title{
Process Window Determination for Biofiltration by the Taguchi Method
}

\author{
Man Chung Law ${ }^{1}$, Hong Chua ${ }^{1}$, Ka Po Cheng ${ }^{2 *}$, Chi Wai Kan ${ }^{3}$ \\ ${ }^{1}$ Department of Civil and Structure Engineering, The Hong Kong Polytechnic University, Hong Kong, China \\ ${ }^{2}$ Department of Industrial Centre, The Hong Kong Polytechnic University, Hong Kong, China \\ ${ }^{3}$ Department of Institute of Textiles and Clothing, The Hong Kong Polytechnic University, Hong Kong, China \\ Email: *karen.kp.cheng@polyu.edu.hk
}

Received August 2, 2012; revised September 3, 2012; accepted October 1, 2012

\begin{abstract}
Raw water from the Yantian Reservoir in Southern China was used for this study. Several process parameters of biofiltration, temperature, media, empty bed contact time, ozone dosage and concentration of geosmin and MIB, were adopted in order to determine their effects. Experiments were conducted using the Taguchi method and 9 experiments were needed to obtain the best process parameter settings and parameter effects. The results of these experiments indicate the use of biological filtration as a method of geosmin and MIB removal, to be satisfactory. In addition, the results show that temperature impacts the removal rate of both geosmin and MIB. Useful insights into the effects of the filter media on such as, empty bed contact time, ozone dosage and concentration of geosmin and MIB were also obtained.
\end{abstract}

Keywords: Taste and Odor; Water Quality; Design of Experiment; Taguchi Method

\section{Introduction}

Yantian reservoir, established in 1976, is situated in Dongguan (Figure 1). It is used mainly as a source of drinking water for the Dongguan area-Fenggang. The area and storage capacity of the Yantian reservoir are equal to approximately $256,000 \mathrm{~m}^{2}$ and $8,990,000 \mathrm{~m}^{3}$ respectively.
From October 2010 to October 2011, the geosmin and MIB concentration of Yantain reservoir are around $3 \mathrm{ng}$ to $168 \mathrm{ng} / \mathrm{L}$ and $4 \mathrm{ng}$ to $139 \mathrm{ng} / \mathrm{L}$ respectively (Figure 2).

Several factors may significantly influence geosmin and MIB removal in biofilters. These factors include such asseasonal water temperature variations, filter me dia (GAC, EC, or sand), empty bed contact time. Some

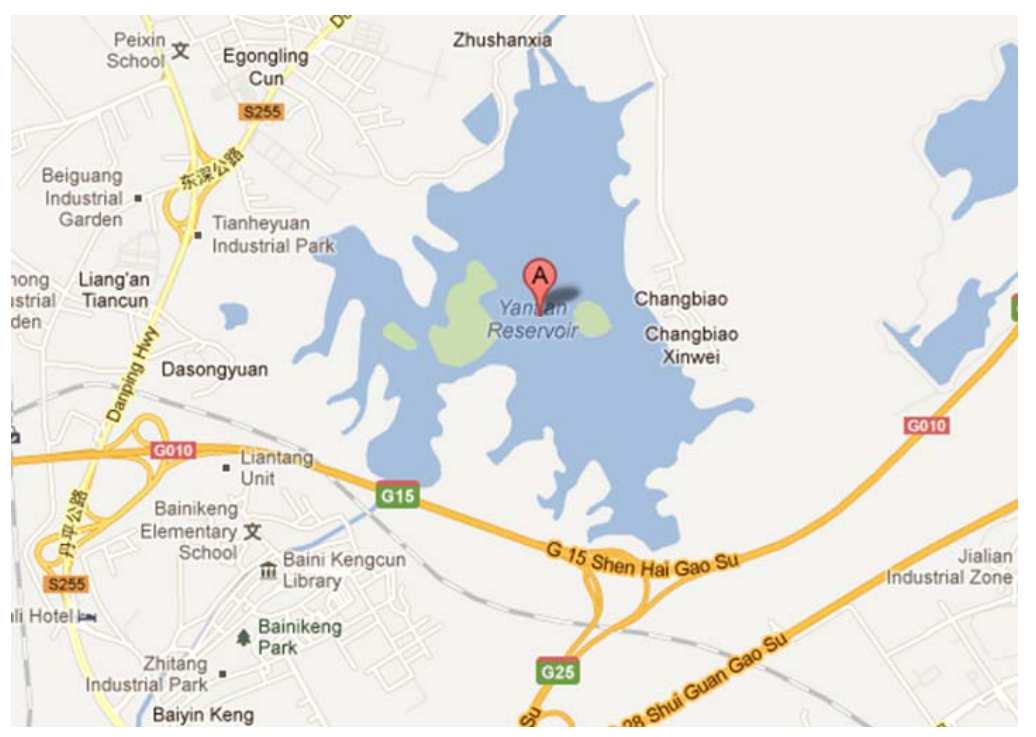

Figure 1. Location of the China's Yantian reservoir.

${ }^{*}$ Corresponding author. 


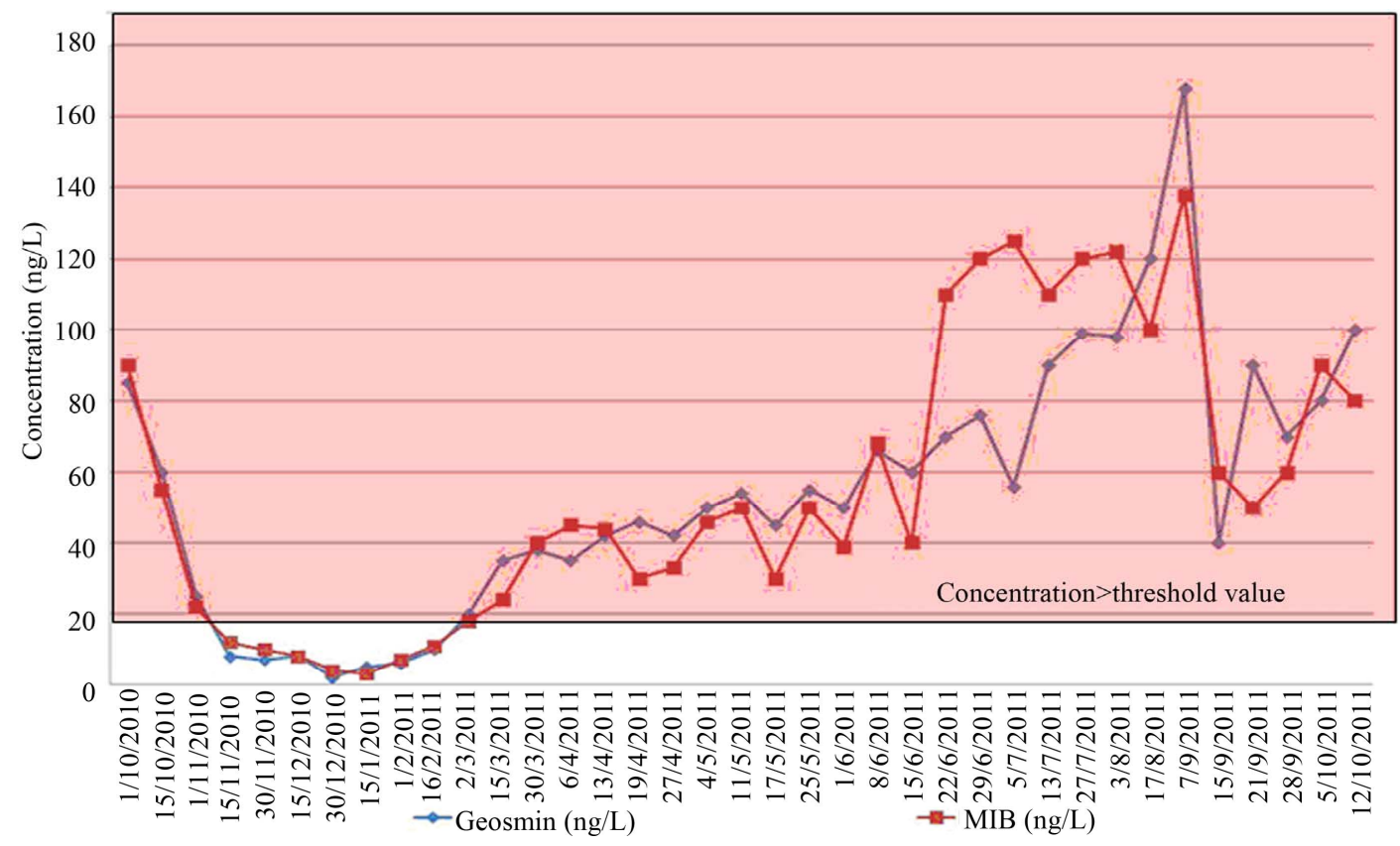

Figure 2. Concentration of geosmin \& MIB for Yantian surface water over a year.

investigations demonstrated that temperature and media are the most important factors affecting drinking water biofiltration processes [1] and may influence the removal of compounds such as geosmin and MIB. In addition, the geosmin and MIB concentrations are important factors affecting their removal in biofilms [2]. In view of the lack of recorded systematic approaches, the best possible outcome is usually achieved by "trial-and-error" or by changing one control variable at a time while holding the rest constant.

The use of DOE enables an increase in the information available and reduces the number of tests required for a given number of factors and levels. If the experiments are designed correctly, a large amount of information can be collected with a minimum of experimental effort. A number of successful DOE applications for improving process performance have been reported over the last 15 years [3-5]. In the case study conducted in this research study, the major factors thought to affect geosmin and MIB removal in biological degradation are examined. These factors include 1) initial concentration; 2) empty bed contact time; 3) ozone dosage; and 4) media.

\section{Methods}

\subsection{Design of Experiment}

Given that a range of values is suggested, experiments should be setup in order to determine the most appropriate. In the case, each of the parameters has a three value level standby, and the maximum possible condition is 81 . This means 81 experiments/columns should be setup to examine the effects of these parameters and the potential interactions among them regarding geosmin and MIB removal. In order to determine/obtain the best process parameter settings, with the least number of experiments, the Taguchi method was selected. Only 9 experiments/ columns were needed to quantify the effects and interactions of 3 or more parameters/factors. As temperature affects the removal rate of geosmin and MIB, two levels of temperature were selected as the noise factor. The high, medium and low levels of control factors selected for the experiments are shown in Table 1. The levels were assigned on the basis of values found in the literature for the different parameters.

\subsection{Isolation of Bacteria}

Due to limited resources, the bacteria source was from the sludge in the aeration tank of Tai Po waste water treatment plant in Hong Kong and the target bacteria used for the development of the biofilter was Bacillus cereus and Pseudomonas-aeruginosa. Bacillus cereus and Pseudomonas-aeruginosa were chosen for the removal of geosmin and MIB as they had been proven to provide effective geosmin and MIB removal [6,7] and their presence in the sludge from the aeration tank of Tai Po waste water treatment plant had been confirmed [8].

$200 \mathrm{~mL}$ of the sludge was put into $3 \mathrm{~L}$ of synthetic water with an internal air pump which supplied oxygen to the bacteria, and aluminum foil was used to cover the bucket to prevent the entry of pollutants. The specimen was kept in the Water and Wastewater Laboratory of the Hong Kong Polytechnic University at a temperature of $18^{\circ} \mathrm{C}$. 
Table 1. The high, medium and low levels of each control factor \& noise factor.

\begin{tabular}{|c|c|c|c|c|c|}
\hline & \multicolumn{4}{|c|}{ Control Factors } & \multirow{2}{*}{ Noise Factor } \\
\hline & A & B & $\mathrm{C}$ & $\mathrm{D}$ & \\
\hline Level & Media & Empty Bed Contact Time (EBCT) & Concentration & Ozone Dosage & Temperature \\
\hline 1 & GAC & 4 mins & 100 ng/L & $1 \mathrm{mg} / \mathrm{L}$ & $10^{\circ} \mathrm{C}$ \\
\hline 2 & $\mathrm{EC}$ & 8 mins & 25 ng/L & $2 \mathrm{mg} / \mathrm{L}$ & $20^{\circ} \mathrm{C}$ \\
\hline 3 & Sand & 12 mins & 50 ng/L & $3 \mathrm{mg} / \mathrm{L}$ & \\
\hline
\end{tabular}

A typical empirical formula for a bacterial cell, $\mathrm{C}_{55} \mathrm{H}_{77} \mathrm{O}_{22} \mathrm{~N}_{11} \mathrm{P}_{2}$ [9], indicates a C:N:P ratio of 21:5:1 (w/w/w). Some Researcher [10] chose a C:N:P ratio of 15:5:1 (w/w/w) to guarantee that the organic carbon was the limiting nutrient. As the sludge contained a variety of bacteria, a specific C:N:P ratio adapted for Bacillus cereus and Pseudomonas-aeruginosa was applied to the mixture aiming at removing other bacteria and accelerating the growth of bacillus cereus and Pseudomonasaeruginosa. The same C:N:P ratio as [10] was used in this study. Glucose $\left(\mathrm{C}_{6} \mathrm{H}_{12} \mathrm{O}_{6}\right)$, ammonia sulfate $\left(\left(\mathrm{NH}_{4}\right)_{2} \cdot \mathrm{SO}_{4}\right)$ and potassium phosphate $\left(\mathrm{K}_{2} \mathrm{HPO}_{4}\right)$ were used as the sources of carbon, nitrogen and phosphor respectively.

The target carbon source $\left(\mathrm{C}_{12} \mathrm{H}_{22} \mathrm{O}\right)$ of concentration $100 \mathrm{mg} / \mathrm{L}$ was chosen, since this concentration is the usual concentration of nutrients adapted by the bacteria in sludge. The calculated nutrient mass was fed every day for 3 weeks.

In order to monitor the condition of the bacteria, the $\mathrm{pH}$ of the mixture was measured every day by a CD510 $\mathrm{pH}$ meter (CD510, WPA) during these 3 weeks. Since a $\mathrm{pH}$ value between 6.5 and 7.2 is the most suitable for the growth of Bacillus cereus [11], the $\mathrm{pH}$ of the mixture was measured to ensure that the condition of the mixture was suitable for the growth of Bacillus cereus and Pseudomonas-aeruginosa. If the $\mathrm{pH}$ of the mixture became out of range, an alkaline solution produced by $1 \mathrm{M} \mathrm{NaOH}$ was added to the mixture to adjust its $\mathrm{pH}$.

The total organic carbon (TOC) of the mixture was measured by a total organic carbon analyzer (TOC-5000 A, Shimadzu). On the first day after the addition of nutrients, the TOC of the mixture was measured and thereafter every day before and after the addition of nutrients. The growth of the microorganisms can be shown by the decrease in the TOC content. Therefore, by having the TOC measurement, the growth of the bacteria was revealed.

Before putting the mixture into the TOC Analyzer, it was filtered to ensure that there were no solids in the liquid that would damage the analyzer. The growth of bacteria could be demonstrated from the TOC measurements, as the decrease of the TOC concentration indicated the growth of bacteria.
The prepared Bacillus cereus was inoculated into the nine columns, three of which were filled with the exhausted GAC, another three were filled with sand and the final three were filled with the prepared EC. Each was connected to one of nine individual water pumps. The flow rate for the mixture into the columns was $3.5 \mathrm{~cm}^{3}$ / minute and the inoculation process was carried out for the duration of two weeks. The comparably low flow rate was intended to allow time for the bacteria to attach to the surface of the media.

The delay in the biological degradation occurrence is regarded as the lag period and lag periods from days to months before complete degradation of organic compounds have been recorded in the literature [12]. The bacteria was fed with glucose as the carbon source originally, thus it may not obtain the carbon nutrient from geosmin or MIB in the water during the biofiltration and hence lead to the lag period. An attempt was made to decrease the lag period prior to degradation of geosmin or MIB occurred in the column. This was conducted by introducing a series of geosmin or MIB spiking trials over a period of two week.

During the two weeks of inoculating the bacteria into the nine columns, nine filter columns were spiked with geosmin and MIB on day 1 of the inoculation. Target concentrations of $100 \mathrm{ng} / \mathrm{L}$ for both geosmin and MIB were introduced into each of the filter influents. These concentrations were in the higher range of what is typically seen in nature and represent the worst case scenario [13]. Finally, a rest period of 3 days was provided before the biodegradation experiments began.

\subsection{Experimental Arrangement}

The experiments were conducted in the Water and Wastewater Laboratory of the Hong Kong Polytechnic University. Nine sets of $25 \mathrm{~mm}$ internal diameter glass columns with a total length of $43 \mathrm{~cm}$ of filter bed were used. Stock solutions of geosmin and MIB (20 ng/L) were prepared by diluting geosmin standard solution (G5908-2 mg/mL in methanol, SIGMA) and MIB standard solution (G5908-2 mg/mL in methanol, SIGMA) in synthetic water. Each set of columns consisted of different media (GAC, EC or Sand), different empty bed 
contact time (4 mins, 8 mins or 12 mins) and different concentrations (25 ng/L, $50 \mathrm{ng} / \mathrm{L}$ or $100 \mathrm{ng} / \mathrm{L}$ ) to filter the deionized water with different ozone dosage $(1,2$ or $3 \mathrm{mg} / \mathrm{L})$ under different temperatures $\left(10^{\circ} \mathrm{C}\right.$ or $\left.20^{\circ} \mathrm{C}\right)$. For example, column 1 was filled with GAC (Filtrasorb 300 with an effective size of 0.8 to $1.0 \mathrm{~mm}$ ) in order to filter the synthetic water with a concentration of $100 \mathrm{ng} / \mathrm{L}$ geosmin and MIB and $1 \mathrm{mg} / \mathrm{L}$ ozone dosage with an empty bed contact time of 4 mins. Column 4 was filled with EC (Filtralite MC with an effective size of 2.45 to $2.75 \mathrm{~mm}$ ) in order to filter the synthetic water with a concentration of $50 \mathrm{ng} / \mathrm{L}$ Geosmin and MIB and $3 \mathrm{mg} / \mathrm{L}$ ozone dosage with empty bed contact time of 4 mins. Column 7 was filled with Sand (effective size of $0.5 \mathrm{~mm}$ ) in order to filter the synthetic water with a concentration of $25 \mathrm{ng} / \mathrm{L}$ Geosmin and MIB and $2 \mathrm{mg} / \mathrm{L}$ ozone dosage with an empty bed contact time of 4 mins. The removal rates of geosmin and MIB were identified at two temperature conditions, $10^{\circ} \mathrm{C}$ and $20^{\circ} \mathrm{C}$ for all 9 columns.

The setup condition for the rest of the columns is shown in Table 2. Each column was connected to an individual water pump. 9 water pumps were connected, in parallel, to pump the water samples, which were stored in individual glass boxes. The air pumps acted as the influent and provided oxygen for the biofilm in each column by the up-flow method.

Based on the L9 layout, the experiments on the 9 columns for the determination of the geosmin and MIB removal rate were run twice at the two temperature conditions of $10^{\circ} \mathrm{C}$ and $20^{\circ} \mathrm{C}$.

\subsection{Solid Phase Microextraction-Gas Chromatography-Mass Spectrometry Analysis}

Solid phase microextraction (SPME) and gas chromatography/mass spectroscopy (GC/MS) were employed to determine the levels of the geosmin and MIB of different process settings. The procedure for the analysis of 2-MIB and geosmin was the same as that prescribed by the standard method 6040D. The method was based on the Solid Phase Micro-Extraction (SPME) concentration. A commercially available SPME fiber (NO. 57328-U Supeloc, US) was selected to concentrate the MIB and geosmin. The fiber was comprised of a composite material with Divinylbenzene, carboxen, and polydimethylsiloxane.

GC-MS analysis was carried out with a Varian Model CP3380 gas chromatograph-mass spectrometer in conjunction with a GCMS Model 1200 L Quadrupole MS/MS. A $5 \%$ phenyl-methyl column VF- 5 ms (Varian, Lake Forest, CA, USA: $30 \mathrm{~mm}(\mathrm{~L}) \times 0.25 \mathrm{~mm}$ (ID) $\times 0.39 \mathrm{~mm}$ (OD) and $0.25 \mu \mathrm{m}$ film thickness) was used.

According to Ligor and Buszewski (2005), the GC operating conditions should be as follows: injection and detector temperatures, $280^{\circ} \mathrm{C}$; column temperature, held at $190^{\circ} \mathrm{C}$ for $2 \mathrm{~min}$, increased to $270^{\circ} \mathrm{C}$ at $10^{\circ} \mathrm{C} / \mathrm{min}$; inlet helium carrier gas flow rate, $1.43 \mathrm{~mL} / \mathrm{min}$ maintained by an electronic pressure controller; split ratio, 5:1. The electron impact (EI)-MS conditions were as follows: ionsource temperature, $200^{\circ} \mathrm{C}$; ionizing voltage, $70 \mathrm{eV}$. Full scan mass spectra were obtained at an $\mathrm{m} / \mathrm{z}$ range of 80 $200 \mathrm{u}$. Selected ion monitoring (SIM) mode detections for MIB and GSM were obtained as $\mathrm{m} / \mathrm{z}=112$ (GSM) and $\mathrm{m} / \mathrm{z}=95$ (MIB). The peak height was measured to construct the calibration curve and to determine the MIB and GSM concentrations in the samples.

\subsection{Statistical Analysis Method}

The removal rate was recorded, enabling the signal-tonoise ratio to be calculated, to determine the variation of each parameter in the removal rate of geosmin and MIB, and also the interaction between the factors. With the aid of ANOVA, the effect of each parameter on the removal rate of geosmin and MIB was calculated.

Table 2. The layout of L9 (34) by taguchi method.

\begin{tabular}{|c|c|c|c|c|}
\hline No & Media & Empty Bed Contact Time (EBCT) & Concentration & Ozone Dosage \\
\hline 1 & GAC & 4 mins & $100 \mathrm{ng} / \mathrm{L}$ & $1 \mathrm{mg} / \mathrm{L}$ \\
\hline 2 & GAC & 8 mins & 25 ng/L & $2 \mathrm{mg} / \mathrm{L}$ \\
\hline 3 & GAC & 12 mins & $50 \mathrm{ng} / \mathrm{L}$ & $3 \mathrm{mg} / \mathrm{L}$ \\
\hline 4 & EC & 4 mins & $50 \mathrm{ng} / \mathrm{L}$ & $3 \mathrm{mg} / \mathrm{L}$ \\
\hline 5 & EC & 8 mins & 100 ng/L & $1 \mathrm{mg} / \mathrm{L}$ \\
\hline 6 & EC & 12 mins & 25 ng/L & $2 \mathrm{mg} / \mathrm{L}$ \\
\hline 7 & Sand & 4 mins & $25 \mathrm{ng} / \mathrm{L}$ & $2 \mathrm{mg} / \mathrm{L}$ \\
\hline 8 & Sand & 8 mins & $50 \mathrm{ng} / \mathrm{L}$ & $3 \mathrm{mg} / \mathrm{L}$ \\
\hline 9 & Sand & 12 mins & 100 ng/L & $1 \mathrm{mg} / \mathrm{L}$ \\
\hline
\end{tabular}




\section{Results and Discussion}

\subsection{Best Process Window for the Removal of Geosmin \& MIB}

The optimum condition for Geosmin was shown in experiment no 1 (media: GAC; EBCT: 4 mins; concentration: $100 \mathrm{ng} / \mathrm{L}$; ozone dosage: $1 \mathrm{mg} / \mathrm{L}$ ) while the optimum condition for MIB was experiment no 1 (media: GAC; EBCT: 4 mins; concentration: $100 \mathrm{ng} / \mathrm{L}$; ozone dosage: $1 \mathrm{mg} / \mathrm{L}$ ). From the experimental results (Table 3 and Figure 3), it is seen that the removal rates of both Geosmin and MIB are better when the working tempera ture is $20^{\circ} \mathrm{C}$.

\subsection{Effect and Interactions of Process Parameters}

Since the removal rate of geosmin and MIB has a larger- the-better characteristic, the $\mathrm{S} / \mathrm{N}$ ratio for a larger-thebetter characteristic is used for the calculation of the total variation. Table 4 shows the $\mathrm{S} / \mathrm{N}$ ratio for experiment No. 1 to 9 and Table 5 shows the square of the $\mathrm{S} / \mathrm{N}$ ratio for experiment No. 1 to 9 .

The correction term (CF) of Geosmin

$=(-86.57)^{2} / 9=832.71$

The correction term (CF) of MIB

$=(-116.33)^{2} / 9=1503.63$

The total variation of the experiment for geosmin:

$\mathrm{ST}=881.79-\mathrm{CF}=881.79-832.71=49.08$

The total variation of the experiment for MIB:

$\mathrm{ST}=1550.32-\mathrm{CF}=1550.32-1503.63=46.69$

For the variation of factors in the removal rate of geosmin, the level totals for the $\mathrm{S} / \mathrm{N}$ ratio of geosmin is calculated and shown in Table 6.

Table 3. The geosmin \& MIB removal rate of each column at two temperature conditions.

\begin{tabular}{|c|c|c|c|c|c|c|c|c|}
\hline \multirow[b]{2}{*}{ No } & \multicolumn{4}{|c|}{ Control Factors } & \multicolumn{2}{|c|}{ Removal Rate of Geosmin } & \multicolumn{2}{|c|}{ Removal Rate of MIB } \\
\hline & Media & Empty Bed Contact Tim (EBCT) & Concentration & Ozone Dosage & $10^{\circ} \mathrm{C}\left(\mathrm{R}_{1}\right)$ & $20^{\circ} \mathrm{C}\left(\mathrm{R}_{2}\right)$ & $10^{\circ} \mathrm{C}\left(\mathrm{r}_{1}\right)$ & $20^{\circ} \mathrm{C}\left(\mathrm{R}_{2}\right)$ \\
\hline 1 & GAC & 4 mins & 100 ng/L & $1 \mathrm{mg} / \mathrm{L}$ & $38 \%$ & $89 \%$ & $24 \%$ & $88 \%$ \\
\hline 2 & GAC & 8 mins & 25 ng/L & $2 \mathrm{mg} / \mathrm{L}$ & $32 \%$ & $81 \%$ & $20 \%$ & $76 \%$ \\
\hline 3 & GAC & 12 mins & 50 ng/L & $3 \mathrm{mg} / \mathrm{L}$ & $33 \%$ & $86 \%$ & $21 \%$ & $80 \%$ \\
\hline 4 & EC & 4 mins & 50 ng/L & $3 \mathrm{mg} / \mathrm{L}$ & $21 \%$ & $32 \%$ & $13 \%$ & $28 \%$ \\
\hline 5 & EC & 8 mins & 100 ng/L & $1 \mathrm{mg} / \mathrm{L}$ & $28 \%$ & $40 \%$ & $19 \%$ & $33 \%$ \\
\hline 6 & EC & 12 mins & 25 ng/L & $2 \mathrm{mg} / \mathrm{L}$ & $19 \%$ & $34 \%$ & $11 \%$ & $22 \%$ \\
\hline 7 & Sand & 4 mins & 25 ng/L & $2 \mathrm{mg} / \mathrm{L}$ & $20 \%$ & $28 \%$ & $16 \%$ & $23 \%$ \\
\hline 8 & Sand & 8 mins & 50 ng/L & $3 \mathrm{mg} / \mathrm{L}$ & $24 \%$ & $56 \%$ & $18 \%$ & $35 \%$ \\
\hline 9 & Sand & 12 mins & 100 ng/L & $1 \mathrm{mg} / \mathrm{L}$ & $30 \%$ & $62 \%$ & $20 \%$ & $48 \%$ \\
\hline
\end{tabular}

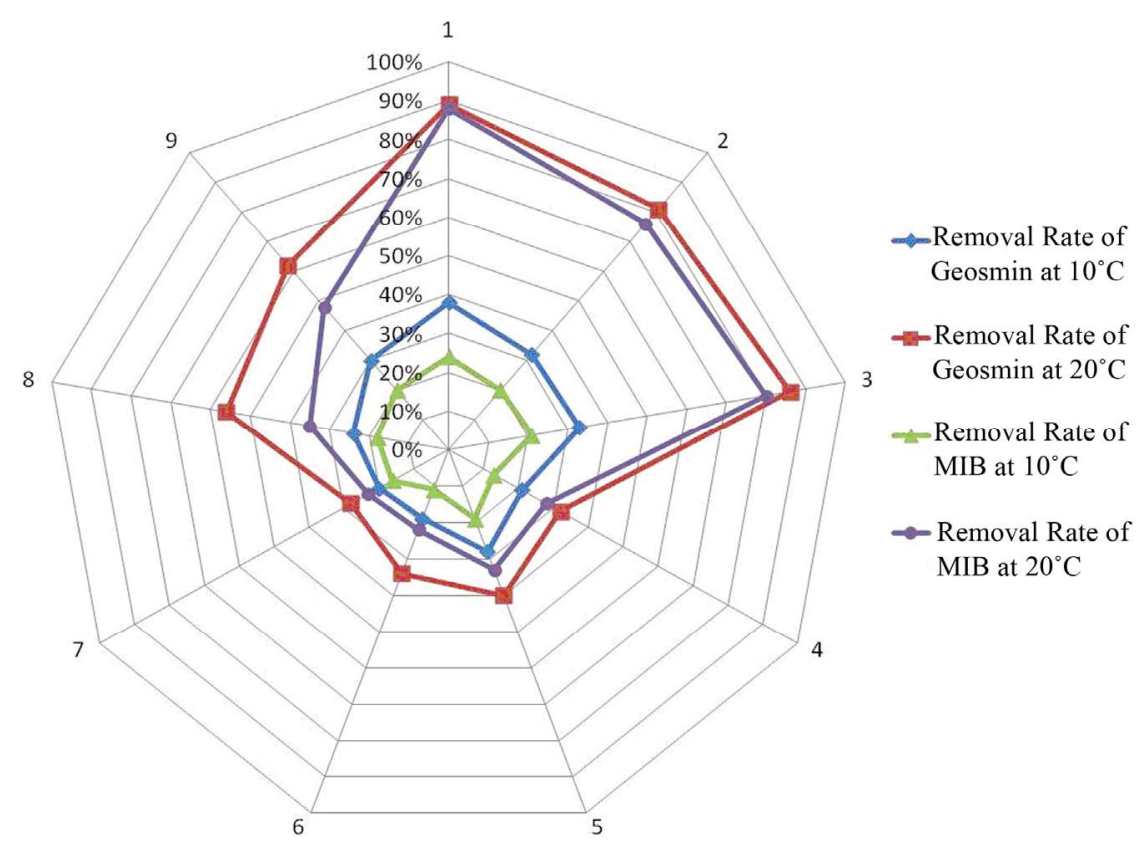

Figure 3. Comparison of geosmin \& MIB removal rate at two temperature conditions (Columns 1 to 9). 
Table 4. List of S/N ratio for the removal rate of geosmin \& MIB.

\begin{tabular}{|c|c|c|c|c|c|c|}
\hline \multirow[b]{2}{*}{ No } & \multicolumn{2}{|c|}{ Removal Rate of Geosmin } & \multicolumn{2}{|c|}{ Removal Rate of MIB } & S/N Ratio of Geosmin (db) & S/N Ratio of MIB (db) \\
\hline & $10^{\circ} \mathrm{C}\left(R_{1}\right)$ & $20^{\circ} \mathrm{C}\left(R_{2}\right)$ & $10^{\circ} \mathrm{C}\left(r_{1}\right)$ & $20^{\circ} \mathrm{C}\left(r_{2}\right)$ & $-\log _{10}\left[\frac{1}{2}\left(\frac{1}{R_{1}^{2}}+\frac{1}{R_{1}^{2}}\right)\right]$ & $-\log _{10}\left[\frac{1}{2}\left(\frac{1}{r_{1}^{2}}+\frac{1}{r_{1}^{2}}\right)\right]$ \\
\hline 1 & 0.38 & 0.89 & 0.24 & 0.88 & -6.12 & -9.70 \\
\hline 2 & 0.32 & 0.81 & 0.20 & 0.76 & -7.52 & -11.26 \\
\hline 3 & 0.33 & 0.86 & 0.21 & 0.80 & -7.22 & -10.83 \\
\hline 4 & 0.21 & 0.32 & 0.13 & 0.28 & -12.10 & -15.56 \\
\hline 5 & 0.28 & 0.40 & 0.19 & 0.33 & -9.78 & -12.66 \\
\hline 6 & 0.19 & 0.34 & 0.11 & 0.22 & -12.59 & -17.13 \\
\hline 7 & 0.20 & 0.28 & 0.16 & 0.23 & -12.76 & -14.62 \\
\hline 8 & 0.24 & 0.56 & 0.18 & 0.35 & -10.12 & -12.90 \\
\hline 9 & 0.30 & 0.62 & 0.20 & 0.48 & -8.36 & -11.66 \\
\hline \multicolumn{5}{|c|}{ Total } & -86.57 & -116.33 \\
\hline
\end{tabular}

Table 5. Square of S/N ratio for experiment no 1 to 9.

\begin{tabular}{ccccc}
\hline No & S/N Ratio of Geosmin $(\mathrm{db})$ & $(\mathrm{S} / \mathrm{N} \text { Ratio of Geosmin })^{2}$ & S/N Ratio of MIB $(\mathrm{db})$ & ${\text { (S/N Ratio of MIB })^{2}}^{2}$ \\
\hline 1 & -6.12 & 37.47 & -9.70 & 94.03 \\
2 & -7.52 & 56.50 & -11.26 & 126.79 \\
3 & -7.22 & 52.07 & -10.83 & 117.39 \\
4 & -12.10 & 146.43 & -15.56 & 242.07 \\
5 & -9.78 & 95.62 & -12.66 & 160.23 \\
6 & -12.59 & 158.63 & -17.13 & 293.47 \\
7 & -12.76 & 162.82 & -14.62 & 213.79 \\
8 & -10.12 & 102.37 & -12.90 & 166.50 \\
9 & -8.36 & 69.90 & -11.66 & 136.07 \\
& Total & 881.79 & Total & 1550.32 \\
\hline
\end{tabular}

The sum of the squares caused by control factor $\mathrm{A}$ is called variation SA

$$
\mathrm{SA}=\left\{\left[(-20.85)^{2}+(-34.47)^{2}+(-31.24)^{2}\right] / 3\right\}-\mathrm{CF}=
$$
33.57

The sum of squares caused by control factor B is called variation $\mathrm{SB}$

$$
\mathrm{SB}=\left\{\left[(-30.98)^{2}+(-27.41)^{2}+(-28.17)^{2}\right] / 3\right\}-\mathrm{CF}=
$$
2.16

The sum of squares caused by control factor $\mathrm{C}$ is called variation $\mathrm{SC}$

$$
\mathrm{SC}=\left\{\left[(-32.87)^{2}+(-29.44)^{2}+(-24.26)^{2}\right] / 3\right\}-\mathrm{CF}=
$$

The sum of squares caused by control factor $\mathrm{D}$ is called variation SD

$$
\mathrm{SD}=\left\{\left[(-24.26)^{2}+(-32.87)^{2}+(-29.44)^{2}\right] / 3\right\}-\mathrm{CF}=
$$
12.52

The total of SA, SB, SC and SD is calculated:

$\mathrm{SA}+\mathrm{SB}+\mathrm{SC}+\mathrm{SD}=33.57+2.16+12.52+12.52=$ 60.77

The variation error $=49.08-60.77=-11.69$

The difference between the total variation and factor variations is found in the interaction between the factors. After the interaction is calculated, the ANOVA table for the removal rate of geosmin and MIB is constructed as shown in Table 7. The removal rates of geosmin and MIB, were most affected by the media.
The same steps are applied for MIB and the level totals for the $\mathrm{S} / \mathrm{N}$ ratio of MIB were calculated and are shown in Table 8.

Table 6. Level totals for $\mathrm{S} / \mathrm{N}$ ratio of geosmin.

\begin{tabular}{ccccc}
\hline \multicolumn{5}{c}{ Control Factors } \\
\hline Level & $\mathrm{A}$ & $\mathrm{B}$ & $\mathrm{C}$ & $\mathrm{D}$ \\
\hline 1 & -20.85 & -30.98 & -32.87 & -24.26 \\
2 & -34.47 & -27.41 & -29.44 & -32.87 \\
3 & -31.24 & -28.17 & -24.26 & -29.44 \\
Total & -86.56 & -86.56 & -86.56 & -86.56 \\
\hline
\end{tabular}

Table 7. ANOVA table for the removal rate of geosmin.

\begin{tabular}{cccc}
\hline Factor & Degree of Freedom & Variation (S) & Variance (V) \\
\hline Media & 2 & 33.76 & 16.88 \\
Empty Bed Contact & 2 & 2.36 & 1.18 \\
Time (EBCT) & 2 & 12.52 & 6.26 \\
Concentration & 2 & 12.52 & 6.26 \\
Ozone Dosage & & & \\
\hline
\end{tabular}

Table 8. Level totals for $\mathrm{S} / \mathrm{N}$ ratio of MIB.

\begin{tabular}{ccccc}
\hline \multicolumn{5}{c}{ Control Factors } \\
\hline Level & A & B & C & D \\
\hline 1 & -31.79 & -39.88 & -43.01 & -34.02 \\
2 & -45.35 & -36.82 & -39.30 & -43.01 \\
3 & -39.19 & -39.63 & -34.02 & -39.29 \\
Total & -116.33 & -116.33 & -116.33 & -116.33 \\
\hline
\end{tabular}


The sum of squares caused by control factor $\mathrm{A}$ is called variation SA

$$
\begin{array}{r}
\mathrm{SA} \\
30.73
\end{array}
$$

The sum of squares caused by control factor B is called variation $\mathrm{SB}$

$$
\begin{aligned}
& \mathrm{SB}=\left\{\left[(-39.88)^{2}+(-36.82)^{2}+(-39.63)^{2}\right] / 3\right\}-\mathrm{CF}= \\
& 1.92
\end{aligned}
$$

The sum of squares caused by control factor $C$ is called variation $\mathrm{SC}$

$$
\mathrm{SC}=\left\{\left[(-43.01)^{2}+(-39.30)^{2}+(-34.02)^{2}\right] / 3\right\}-\mathrm{CF}=
$$
13.61

The sum of squares caused by control factor $\mathrm{D}$ is called variation $\mathrm{SD}$

$$
\mathrm{SD}=\left\{\left[(-34.02)^{2}+(-43.01)^{2}+(-39.29)^{2}\right] / 3\right\}-\mathrm{CF}=
$$$$
13.34
$$

The total of SA, SB, SC and SD is calculated:

$\mathrm{SA}+\mathrm{SB}+\mathrm{SC}+\mathrm{SD}=30.71+1.92+13.61+13.34=$ 59.58

The variation error $=46.69-59.58=-12.89$

The difference between the total variation and variation of factors is the interaction between the factors. After the interaction was calculated, the ANOVA table was constructed as shown in Table 9. The removal rates of geosmin and MIB, were most affected by the media.

\section{Conclusion}

As stated in the introduction, the use of the Taguchi method can help the water reservoir operation in the identification of the critical process parameters. The coding of independent variables (influent concentration, Ozone dosage, temperature, media and EBCT) for the Taguchi Analysis is shown in the Table 1, where it can be confirmed that temperature is shown to increase the biodegradability of geosmin and MIB, often leading to enhanced removal of geosmin and MIB across the biofilter. The removal rates of geosmin and MIB, were most affected by the media and were substantially larger than their interactions. The EBCT value had the least effect on removal rates in this study. This result could help the water reservoir to identify of the critical process parameters for biofiltration on site.

Table 9. ANOVA table for the removal rate of MIB.

\begin{tabular}{cccc}
\hline Factor & Degree of Freedom Variation (S) & Variance (V) \\
\hline $\begin{array}{c}\text { Media } \\
\text { Empty Bed Contact } \\
\text { Time (EBCT) }\end{array}$ & 2 & 30.71 & 15.36 \\
Concentration & 2 & 1.92 & 0.96 \\
Ozone Dosage & 2 & 13.61 & 6.81 \\
\hline
\end{tabular}

\section{Acknowledgements}

This work was funded by Yantian reservoir in China and the Hong Kong Polytechnic University. I would like to thank the Water and Waste Water Laboratory for supporting this project.

\section{REFERENCES}

[1] D. Urfer, "Effects of Oxidants on Drinking Water Biofilters," Ph.D. Thesis, Department of Civil Engineering, University of Waterloo, Waterloo, 1988.

[2] E. Namkung and B. E. Rittmann, "Removal of Taste- and Odor-Causing Compounds by Biofilms Grown on Humic Substances," Journal of the American Water Works Association, Vol. 79, No. 7, 1987, pp. 107-112.

[3] J. Antony, "Improving the Wire Bonding Process Quality Using Statistically Designed Experiments,” Microelectronics Journal, Vol. 30, No. 2, 1999, pp. 161-168. doi:10.1016/S0026-2692(98)00104-9

[4] R. G. Bullington, et al., "Improvement of an Industrial Thermostat Using Designed Experiments," Journal of Quality Technology, Vol. 25, No. 4, 1993, pp. 262-271.

[5] M. Hamada, "Using Statistically Designed Experiments to Improve Reliability and to Achieve Robust Reliability,” IEEE Transactions on Reliability, Vol. 44, No. 2, 1995, pp. 206-215. doi:10.1109/24.387372

[6] M. Yagi, S. Nakashima and S. Muramoto, "Biological Degradation of Musty Odorcompounds, 2-Methylisoborneol and Geosmin, in a Bio-Activated Carbon Filter," Water Science \& Technology, Vol. 20, No. 8-9, 1988, pp. 255-260.

[7] D. G. Bourne, G. J. Jones, R. L. Blakeley, A. Jones, A. P. Negri and P. Riddles, "Enzymatic Pathway for the Bacterial Degradation of the Cyanobacterial Cyclic Peptide Toxin Microcystin LR,” Applied \& Environmental Microbiology, Vol. 62, No. 11, 1996, pp. 4086-4094.

[8] Y. F. Tsang, "A Novel Biofiltration Technology for Odour Treatment,” PhD Thesis, Department of Civil and Structure Engineering, The Hong Kong Polytechnic University, Hong Kong, 2009.

[9] G. Tchobanoglous and F. L. Burton, "Wastewater Engineering: Treatment, Disposal, and Reuse,” Metcalf and Eddy, McGraw-Hill, New York, 1991.

[10] D. Urfer, P. M. Huck, S. D. J. Booth and B. M. Coffey, "Biological Filtration for BOM and Particule Removal: A Critical Review," Journal of American Water Works Association, Vol. 89, No. 12, 1997, pp. 83-98.

[11] M. Bridget, H. Daniel, N. Gayle, P. Christopher and H. Lionel, "Enhancing the Biofiltration of Geosmin by Seeding Sand Filter Columns with a Consortium of GeosminDegrading Bacteria,” Water Research, Vol. 43, 2009, pp. 433-440. doi:10.1016/j.watres.2008.10.044

[12] S. W. H. Lionel, "The Removal of Cyanobacterial Metabolites from Drinking Water Using Ozone and Granular Activated Carbon," University of South Australia, Adelaide, 2004.

[13] S. L. N. Elhadi, et al., "Removal of Geosmin and 2-Methylisoborneol," Biological Filtration Water Science \& Technology, Vol. 49, No. 9, 2004, pp. 273-280. 